\title{
Use of illicit drugs by adolescents and young adults of an urban settlement in Brazil
}

\author{
Rafael Alves Guimarães ${ }^{1 *}$ ○, Márcia Maria de Souza ${ }^{1}$, Karlla Antonieta Amorim Caetano $^{1}$, Sheila Araujo Teles ${ }^{1}$, \\ Marcos André de Matos ${ }^{1}$

\section{SUMMARY}

Objective: To estimate the prevalence and factors associated with illicit drug use by adolescents and young adults of a formal urban settlement.

Method: Cross-sectional study including adolescents and young adults 12-24 years of an urban settlement in the Midwest Region of Brazil. Data were collected using a structured questionnaire and analyzed using Stata, version 12.0. We used Poisson regression model to estimate the factors associated with illicit drug use. Results: Of the total participants ( $\mathrm{n}=105$ ), 27.6\% (95CI 20.0-36.9\%) had used illicit drugs such as marijuana, cocaine, crack, LSD and inhalants. The consumption of these substances was associated with male gender, use of body piercing and/or tattoos, licit drug use and self-report of signs and/or symptoms of sexually transmitted infections.

Conclusion: High prevalence of illicit drug use was found in the individuals investigated, ratifying the presence of risk factors to the vulnerability of the settlers to use these substances in the urban settlement population.

Keywords: Street Drugs. Adolescent. Young Adult. Urban Area.

\section{INTRODUCTION}

The consumption of illicit drugs represents an important public health problem worldwide, and especially in developing countries such as Brazil. ${ }^{1}$ The use of these substances is associated with multiple consequences, including violence, traffic accidents, impaired psychosocial development, infectious diseases, mental disorder and suicide, particularly in the young population., ${ }^{2,3} \mathrm{~A}$ total of 246 million people aged 15-64 are estimated to have used illicit drugs in 2013 around the world. ${ }^{1}$

The prevalence of illicit drug use among adolescents and young people is high, and these groups are considered to be highly vulnerable to substance abuse. ${ }^{4}$ Multiple factors are associated with the use of drugs in these populations, including sociodemographic characteristics, risk behaviors, exposure to situations of violence and use of licit substances, namely alcohol and tobacco. ${ }^{4-7}$ Also, studies indicate the use of illicit drugs as a predictor of sexually transmitted infections (STIs), including human immunodeficiency virus (HIV). ${ }^{8}$

In Brazil, there are still no investigations into the use of illicit drugs in individuals from urban settlements, who are potentially vulnerable to these substances. In addition, there are no studies on the potential risk factors for illicit drug use in the population of urban settlements in the country. Some studies show that people living in urban settlements have a high prevalence of illicit drug use, ${ }^{9,10}$ and that may contribute to the increase of morbidity and mortality due to diseases associated with the use of these substances. Thus, the objective of our study was to estimate the prevalence and factors associated with the use of illicit drugs by adolescents and young adults in a formal urban settlement.

\section{Method}

This is a cross-sectional cohort study of adolescents and young adults from a formal urban settlement in the city of Goiânia, Midwestern Brazil, previously described. The inclusion criteria were: (i) to be between 12 and 24 years old and (ii) to have been living in the settlement for at least 12 months. Data were collected between June and July 2014.

Participants were recruited at the institution of education of the settlement or by indication of their peers (friends or relatives). After the consent of the individuals and/or their legal guardians, all the participants were 
interviewed in person in the premises of the educational institution or local basic health unit, using a structured questionnaire on sociodemographic and behavioral data as well as consumption of legal and illegal drugs.

\section{Study variables}

- Outcome variable: Self-reported use of illicit drugs (marijuana, crack, cocaine, LSD and inhalants) in the past 12 months.

- Predictor variable: Sociodemographic characteristics (gender [male versus female], age [12-18 versus 19-24 years], education $[\leq 6$ versus $>6$ years of formal education], marital status of the parents [married/common law partner versus single/separated/widowed], formal or informal employment [no versus yes]), behavioral characteristics (use of body piercing and/or tattoos [no versus yes], use of licit drugs [no versus yes], criminal records [no versus yes], signs or symptoms of STI [no versus yes] and access to a Basic Health Unit [UBS, public health care] [yes versus no]. The categorization of age between 12-18 years and 19-24 years was based on the Brazilian Statute of the Child and the Adolescent. ${ }^{11}$ Licit drug use was defined as the use of alcohol and/or tobacco in the past 30 days. Signs or symptoms of STI were considered positive in the presence of self-reported genital discharge and/or genital ulcer at any time in life. ${ }^{12}$

\section{Statistical analysis}

Data analysis was performed using Stata software version 12.0. Prevalences of illicit drug use were calculated with a confidence interval of $95 \%$ (95CI). Initially, a bivariate analysis was performed between the outcome and potential associated factors. Variables with $\mathrm{p}<0.10$ were entered into the Poisson regression model with robust variance. ${ }^{13}$ Potential confounders were adjusted for the multivariate model. $\mathrm{p}$ values $<0.05$ were considered statistically significant.

\section{Ethical aspects}

Our study was approved by the Research Ethics Committee of the Federal University of Goiás, protocol no. 365/2011. All individuals aged 18 years or older or parents/guardians of individuals under the age of 18 signed a consent form.

\section{Results}

A total of 105 participants were included in the study, $58.1 \%$ were male. Means for age, education and time living in the settlement were 16.2 years $(\mathrm{SD} \pm 3.32), 7.76$ years (SD \pm 1.75 ; min.: 3 ; max.: 12$)$ and 2.73 years $(S D \pm 0.94$; min.:1, max.: 5), respectively.
The prevalence of use of illicit drugs in the past 12 months was $27.6 \%$ (95CI 20.0-36.9\%). In addition, use of marijuana, cocaine, crack, LSD and inhalants was reported by $24.8 \%$ (95CI $17.5-33.8 \%$ ), $6.7 \%$ (95CI $3.3-13.1 \%$ ), $2.9 \%$ (95CI $1.0-8.1 \%$ ), $1.9 \%$ (95CI $0.5-6.7 \%$ ) and $1.0 \%$ (95CI 0.2-5.2\%) of the participants, respectively (Figure 1).

In our study, gender, age, employment, criminal records, use of body piercing and/or tattoos, and consumption of licit drugs were associated with the outcome in the bivariate analysis $(\mathrm{p}<0.05)$. These variables, as well as the presence of signs and/or symptoms of STI, were entered into the multivariate model. After controlling for the confounding variables, male gender (adjusted prevalence ratio [APR]: 2.6; 95CI 1.3-5.2), use of body piercing and/or tattoo (APR: 2.6; 95CI 1.2-5.6), consumption of licit drugs (APR: 3.4; 95CI 1.1-11.6) and presence of signs and/or symptoms of STI (APR: 1.7; 95CI 1.1 -2.8) were statistically associated with consumption of illicit drugs (Table 1).

\section{Discussion}

Estimating prevalence and assessing factors associated with illicit drug use among adolescents and young adults, especially in vulnerable groups such as urban settlement areas, contributes to the formulation of public health policies aimed at preventing and controling the use of these substances, which have a strong negative impact on adult life. Our study presents the first data on the epidemiology of illicit drug use in individuals living in urban settlements in Brazil.

The prevalence of illicit drug use found by us $(27.6 \%$; 95CI 20.0-36.9\%) was nine times higher than that estimated in adolescents from a population-based study in Brazil (2.8\%; 95CI 2.3-4.8\%), ${ }^{14}$ ratifying the vulnerability of these individuals to the consumption of these substances. Consumption of cocaine and crack is associated with a series of consequences for the health condition and social relations of a person, including mental disorders, STIs and violence. ${ }^{15-17}$ Brazil's Midwest concentrates the highest rates of cocaine and crack consumption due to its proximity to other drug-producing countries and is considered a key region for the circulation of these substances to other areas in the country. ${ }^{18}$ We observed high rates of cocaine and crack consumption, indicating a need for the implementation of public policies to prevent drug abuse among dwellers of urban settlements.

Male individuals showed a prevalence 2.6 (95CI 1.3-5.2) times higher for use of illicit drugs compared with women, corroborating the findings of other studies that included adolescents and young adults. ${ }^{6}, 14$ Differences between the sexes are present in the multiple phases of drug abuse 


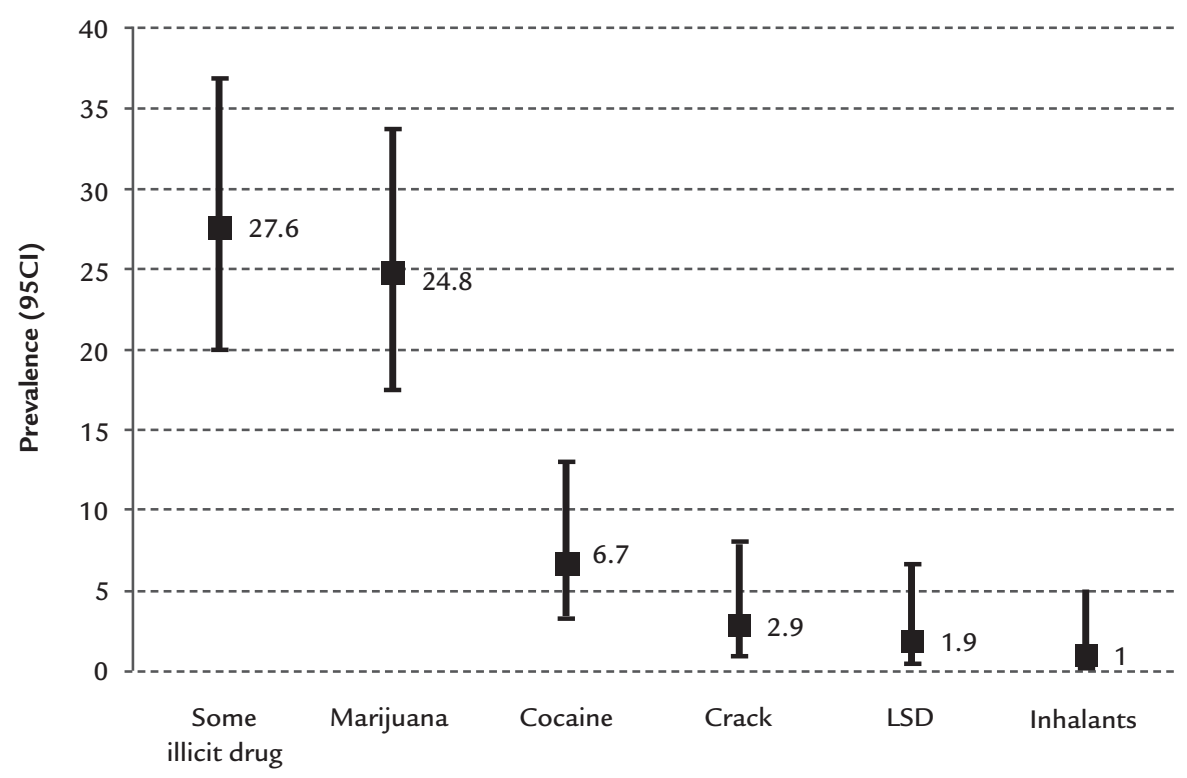

Illicit drug use

FIGURE 1 Prevalence of illicit drug use by adolescents and young adults in an urban settlement. Goiânia, State of Goiás, Brazil, 2013.

TABLE 1 Factors associated with illicit drug use by adolescents and young adults in an urban settlement. State of Goiás, Brazil, 2013.

\begin{tabular}{|c|c|c|c|c|c|c|}
\hline \multirow[t]{2}{*}{ Variables } & \multicolumn{2}{|c|}{ Illicit drug use } & \multirow[t]{2}{*}{$\mathrm{PR}^{\dagger}$, crude $(95 \mathrm{Cl})^{\ddagger}$} & \multirow[t]{2}{*}{$\mathbf{p}$} & \multirow[t]{2}{*}{$\mathrm{PR}^{\dagger}$, adjusted ${ }^{\S}(95 \mathrm{CI})^{\ddagger}$} & \multirow[t]{2}{*}{$\mathbf{p}$} \\
\hline & n/Total* & $\%$ & & & & \\
\hline \multicolumn{7}{|l|}{ Sex } \\
\hline Female & $7 / 44$ & 15.9 & 1.0 & & 1.0 & \\
\hline Male & $22 / 61$ & 36.1 & $2.3(1.1-4.9)$ & 0.04 & $2.6(1.3-5.2)$ & $<0.01$ \\
\hline \multicolumn{7}{|l|}{ Age (years) } \\
\hline $12-18$ & $16 / 77$ & 20.8 & 1.0 & & 1.0 & \\
\hline $19-24$ & $13 / 28$ & 46.4 & $2.2(1.2-4.0)$ & $<0.01$ & $1.1(0.7-1.8)$ & 0.62 \\
\hline \multicolumn{7}{|l|}{ Education (years) } \\
\hline$\leq 6$ & $8 / 27$ & 29.6 & 1.0 & & - & \\
\hline$>6$ & $21 / 78$ & 26.9 & $0.90(0.45-1.81)$ & 0.78 & - & - \\
\hline \multicolumn{7}{|l|}{ Marital status of the parents } \\
\hline Married/Common law partners & $9 / 44$ & 20.4 & 1.0 & & - & \\
\hline Single/separated/widowed & $20 / 61$ & 32.9 & $1.60(0.80-3.18)$ & 0.18 & - & - \\
\hline \multicolumn{7}{|l|}{ Formal or informal employment } \\
\hline No & $13 / 70$ & 20.0 & 1.0 & & 1.0 & \\
\hline Yes & $15 / 35$ & 42.9 & $2.2(1.2-4.1)$ & $<0.01$ & $1.1(0.7-1.7)$ & 0.80 \\
\hline \multicolumn{7}{|l|}{ Criminal records"I } \\
\hline No & $24 / 97$ & 24.7 & 1.0 & & 1.0 & \\
\hline Yes & $5 / 8$ & 62.5 & $2.5(1.3-4.8)$ & $<0.01$ & $1.9(1.0-3.6)$ & 0.06 \\
\hline \multicolumn{7}{|l|}{ Use of body piercing/tattoos } \\
\hline No & $7 / 54$ & 13.0 & 1.0 & & 1.0 & \\
\hline Yes & $22 / 51$ & 43.1 & $3.3(1.6-7.1)$ & $<0.01$ & $2.6(1.2-5.6)$ & 0.01 \\
\hline
\end{tabular}


TABLE 1 (Cont.) Factors associated with illicit drug use by adolescents and young adults in an urban settlement. State of Goiás, Brazil, 2013.

\begin{tabular}{|c|c|c|c|c|c|c|}
\hline \multirow[t]{2}{*}{ Variables } & \multicolumn{2}{|c|}{ Illicit drug use } & \multirow[t]{2}{*}{$\mathrm{PR}^{\dagger}$, crude $(95 \mathrm{Cl})^{\ddagger}$} & \multirow[t]{2}{*}{$\mathbf{p}$} & \multirow[t]{2}{*}{$\mathrm{PR}^{\dagger}$, adjusted $^{\S}(95 \mathrm{CI})^{\ddagger}$} & \multirow[t]{2}{*}{$\mathbf{p}$} \\
\hline & n/Total* & $\%$ & & & & \\
\hline \multicolumn{7}{|c|}{ Licit drug use ${ }^{\|}$} \\
\hline No & $3 / 46$ & 6.5 & 1.0 & & 1.0 & \\
\hline Yes & $26 / 59$ & 44.1 & $6.8(2.2-21.0)$ & $<0.01$ & $3.4(1.1-11.6)$ & 0.04 \\
\hline \multicolumn{7}{|c|}{ Signs and/or symptoms of STIII } \\
\hline No & $19 / 81$ & 23.9 & 1.0 & & 1.0 & \\
\hline Yes & $9 / 21$ & 42.9 & $1.8(1.0-3.4)$ & 0.06 & $1.7(1.1-2.8)$ & 0.03 \\
\hline \multicolumn{7}{|c|}{ User of UBS (public health service) } \\
\hline Yes & $20 / 68$ & 29.4 & 1.0 & & - & \\
\hline No & $9 / 37$ & 24.3 & $0.82(0.41-1.63)$ & 0.58 & - & - \\
\hline
\end{tabular}

(initiation, increased use and dependence) and should be considered in planning health promotion actions in adolescents and young adults. ${ }^{19}$

Use of body piercing and/or tattoos, practices increasingly common in adolescence and youth, has remained associated with the use of illicit drugs (APR: 2.6; 95CI 1.2-5.6). Studies ${ }^{20,21}$ have demonstrated that changes in the body are associated with risk behaviors, such as alcohol consumption and use of illicit drugs. Considering the relation between body piercing and/or tattoo and risk behaviors, changes in the body should be markers evaluated by health professionals while assisting the populations of adolescents and young adults, with a view to screening the use of illicit drugs and health problems arising from abuse of these substances.

Polydrug use is associated with multiple health consequences, including mental disorders and infectious diseases. ${ }^{22}$ In young adults, it is related with progression to drug abuse and increased risk of chemical dependence. ${ }^{22}$ In this study, we found a positive association between licit (APR: 2.4; 95CI 1.1-11.6) and illicit drug use, corroborating the findings described in the domestic and international literature.

Individuals who reported signs and/or symptoms of STI had a prevalence 1.7 (95CI 1.1-2.8) greater of use of illicit drugs compared to those who did not present this clinical picture. Illicit drug use corresponds to an important predictor of STI vulnerability, since they increase the chances of exposure to risk behaviors/attitudes. ${ }^{23}$ Using these drugs increases the disinhibition factor, decreases the perception of risk and negotiation capacity for condom use, ${ }^{24}$ also increases the individual's vulnerability to STIs. In addition, the presence of discharge and/or genital ulcers is associated with HIV infection and increases up to 10 times the chance of viral acquisition and transmission, contributing to increase the burden of this infection in adolescents and young adults. ${ }^{8}$

Our research has some limitations due to the design of cross-sectional studies, which do not allow the establishment of temporality between exposure and outcome. In addition, the data are self-reported, liable to memory bias and underestimation due to questions sensitive to morals. In an attempt to minimize bias, the interviews were conducted individually in a private setting.

\section{Conclusion}

We found a high prevalence of illicit drug use in this population. The use of drugs was associated with the male gender, use of body piercing and/or tattoos, consumption of licit drugs and reporting of signs and/or symptoms of STIs. In this context, implementing interventional actions and public health policies to prevent illicit drug use and its consequences is a pressing issue, considering the associated factors and peculiarities of this emerging social group.

\section{Resumo}

Uso de drogas ilícitas por adolescentes e adultos jovens de um assentamento urbano no Brasil

Objetivo: Estimar a prevalência e fatores associados ao consumo de drogas ilícitas por adolescentes e adultos jovens de um assentamento urbano formal.

Método: Estudo de corte transversal conduzido em adolescentes e adultos jovens de 12 a 24 anos de um assentamento urbano da região Centro-oeste do Brasil. Os dados foram coletados por meio de um questionário estruturado e analisados no programa Stata, versão 12.0. Utilizou- 
-se modelo de regressão de Poisson com variância robusta para estimar os fatores associados ao uso de drogas ilícitas. Resultados: Do total de participantes ( $\mathrm{n}=105), 27,6 \%$ (IC95\% 20,0-36,9\%) reportaram uso de drogas ilícitas, como maconha, cocaína, crack, LSD e inalantes nos últimos 30 dias. O consumo dessas substâncias foi associado a sexo masculino, uso de body piercing e/ou tatuagem, consumo de drogas lícitas (álcool e/ou tabaco) e autorrelato de sinais e/ou sintomas de infecções sexualmente transmissíveis.

Conclusão: Verificou-se alta prevalência de consumo de drogas ilícitas nos indivíduos investigados, ratificando a presença de fatores de risco para uso dessas substâncias na população de assentamento urbano.

Palavras-chave: Drogas Ilícitas. Adolescente. Adulto Jovem. Área Urbana.

\section{References}

1. United Nations Office on Drugs and Crime. World Drug Report 2015. 2015 [cited 06 Jan 2017]. Available from: https://www.unodc.org/documents/ wdr2015/World_Drug_Report_2015.pdf

2. Alwan H, Viswanathan B, Rousson V, Paccaud F, Bovet P. Association between substance use and psychosocial characteristics among adolescents of the Seychelles. BMC Pediatr. 2011;11:85.

3. Degenhardt L, Hall W. Extent of illicit drug use and dependence, and their contribution to the global burden of disease. Lancet. 2012;379(9810):55-70.

4. Medina-Mora ME, Gibbs SE. Implications of science for illicit drug use policies for adolescents in low- and middle-income countries. J Adolesc Health. 2013; 52(2 Suppl 2):S33-5.

5. Pengpid S, Peltzer K. Prevalence and psychosocial correlates of illicit drug use among school-going adolescents in Thailand. J Soc Sci. 2013; 34(3):269-75.

6. Benotsch EG, Snipes DJ, Martin AM, Bul SS. Sexting, substance use, and sexual risk behavior in young adults. J Adolesc Health. 2013; 52(3):307-13.

7. Yusoff F, Sahril N, Rasidi NM, Zaki NA, Muhamad N, Ahmad N. Illicit drug use among school-going adolescents in Malaysia. Asia Pac J Public Health. 2014; 26 (5 Suppl):100S-7S.

8. Santelli JS, Edelstein ZR, Mathur S, Wei Y, Zhang W, Orr MG, et al. Behavioral, biological, and demographic risk and protective factors for new HIV infections among youth, Rakai, Uganda. J Acquir Immune Defic Syndr. 2013; 63(3):393-400.
9. Ayah R, Joshi MD, Wanjiru R, Njau EK, Otieno CF, Njeru EK, et al. A population-based survey of prevalence of diabetes and correlates in an urban slum community in Nairobi, Kenya. BMC Public Health. 2013; 13:371.

10. Angkurawaranon C, Jiraporncharoen W, Chenthanakij B, Doyle P, Nitsch D. Urbanization and non-communicable disease in Southeast Asia: a review of current evidence. Public Health. 2014; 128(10):886-95.

11. Presidência da República, Casa Civil, Subchefia para Assuntos Jurídicos. Lei n. 8.069, de 13 de julho de 1990. Dispõe sobre o Estatuto da Criança e do Adolescente e dá outras providências. 1990 [cited 15 Marc 2017]. Available from: http://www.planalto.gov.br/ccivil_03/leis/L8069.htm.

12. Carvalho PMRS, Guimarães RA, Moraes PA, Teles SA, Matos MA. Prevalence of signs and symptoms and knowledge about sexually transmitted diseases. Acta Paul Enferm. 2015; 28(1):95-100.

13. Coutinho LM, Scazufca M, Menezes PR. Methods for estimating prevalence ratios in cross-sectional studies. Rev Saude Publica. 2008; 42(6):992-8.

14. Madruga CS, Laranjeira R, Caetano R, Pinsky I, Zaleski M, Ferri CP. Use of licit and illicit substances among adolescents in Brazil: a national survey. Addict Behav. 2012; 37(10):1171-5.

15. Narvaez J, Jansen K, Pinheiro RT, Kapczinski F, Silva RA, Pechansky F, et al. Violent and sexual behaviors and lifetime use of crack cocaine: a populationbased study in Brazil. Soc Psychiatry Psychiatr Epidemiol. 2014; 49(8):1249-55.

16. Narvaez JC, Jansen K, Pinheiro RT, Kapczinski F, Silva RA, Pechansky F, et al. Psychiatric and substance-use comorbidities associated with lifetime crack cocaine use in young adults in the general population. Compr Psychiatry. 2014; 55(6):1369-76.

17. Guimarães RA, Silva LN, França DD, Del-Rios NH, Carneiro MA, Teles SA. Risk behaviors for sexually transmitted diseases among crack users. Rev Lat Am Enfermagem. 2015; 23(4):628-34.

18. Abdalla RR, Madruga CS, Ribeiro M, Pinsky I, Caetano R, Laranjeira R. Prevalence of cocaine use in Brazil: data from the II Brazilian national alcohol and drugs survey (BNADS). Addict Behav. 2014; 39(1):297-301.

19. Becker JB, Hu M. Sex differences in drug abuse. Front Neuroendocrinol. 2008; 29(1):36-47.

20. Nowosielski K, Sipiński A, Kuczerawy I, Kozłowska-Rup D, SkrzypulecPlinta V. Tattoos, piercing, and sexual behaviors in young adults. J Sex Med. 2012; 9(9):2307-14

21. Heywood W, Patrick K, Smith AM, Simpson JM, Pitts MK, Richters J, et al. Who gets tattoos? Demographic and behavioral correlates of ever being tattooed in a representative sample of men and women. Ann Epidemiol. 2012; 22(1):51-6.

22. Connor JP, Gullo MJ, White A, Kelly AB. Polysubstance use: diagnostic challenges, patterns of use and health. Curr Opin Psychiatry. 2014; 27(4):269-75.

23. Uppal A, Chou KJ. Screening adolescents for sexually transmitted infections in the pediatric emergency department. Pediatr Emerg Care. 2015;31(1):20-4.

24. Tucker JS, Wenzel SL, Elliott MN, Marshall GN, Williamson S. Interpersonal violence, substance use, and HIV-related behavior and cognitions: a prospective study of impoverished women in Los Angeles County. AIDS Behav. 2004; 8(4):463-74. 